\title{
An antibiotic policy for bacterial infections after thoracic and other injuries
}

\author{
S. T. ATHERTON ${ }^{1}$, D. M. WRIGHT ${ }^{2}$, D. J. WHITE, AND E. S. JONES \\ From the Intensive Care Unit and Pathology Department, Whiston Hospital, Prescot, \\ Merseyside, $U K$
}

\begin{abstract}
Atherton, S. T., Wright, D. M., White, D. J., and Jones, E. S. (1977). Thorax, 32, 596-600. An antibiotic policy for bacterial infections after thoracic and other injuries. Twenty-four patients suffering from thoracic and other injuries were admitted to an intensive care unit over a three-year period. The first four patients died from infection by Gram-negative bacilli with associated features of bacterial toxaemia although it was anticipated that most, if not all, of the patients would have recovered with intensive care. Antibiotics had been started when a patient showed signs of bacterial toxaemia but were ineffective. Retrospective analysis showed that, in each patient, a rapid rise in rectal temperature, white cell count, and blood sugar preceded the clinical features of bacterial toxaemia by one or two days. These observations were incorporated into an antibiotic policy for patients with similar injuries.

The criteria for starting two or three wide spectrum antibiotics were as follows: (1) Gramnegative bacilli in the tracheal aspirate together with radiological evidence of consolidation or absorption collapse; (ii) two of the following three signs-a rectal temperature of $38.5^{\circ} \mathrm{C}$ or more, a white blood cell count of $11.0 \times 10^{9} / 1$ or above, a blood glucose of $11.2 \mathrm{mmol} / 1$ or above; (iii) laparotomy. This policy was tested out over two years on 20 patients with thoracic and other injuries. Sixteen of the patients fulfilled the criteria for antibiotic therapy. Two of the six deaths were due to bacterial infection with toxaemia, a result which suggests that the policy was beneficial.
\end{abstract}

Bacterial infection or toxaemia is an important cause of death in patients with crushed chests or severe multiple injuries, especially when ventilator treatment is necessary. In such patients it is often difficult to decide when relatively harmless bacterial colonisation of the respiratory tract develops into infection or toxaemia. The death rate and morbidity from bacterial infection or toxaemia is high despite intensive therapy with antibiotics effective against the causative organisms. In the past, antibiotic policies for such patients have varied from unit to unit or from patient to patient in the same unit. Thus an antibiotic may be given to all such patients in the hope of preventing bacterial infection; alternatively, therapy is started only when pulmonary infection, bacteraemia or toxaemia are evident. We have carried out an uncontrolled trial of a new antibiotic policy which depends on

'Present address: Royal Infirmary, Castle Street, Glasgow, UK ${ }^{2}$ Present address: Princess Alexandra Hospital, Brisbane, Queensland, Australia giving broad spectrum antibiotics when certain $\times$ criteria are fulfilled. The criteria are based on nonspecific clinical, laboratory, or radiological signs and are taken as evidence of bacterial infection or toxaemia; the observations can be made simply and quickly.

\section{Methods}

The patients were treated in a general intensive care unit established in 1964 (Lancet, 1964). Wheno indicated, crushing injuries of the chest werew treated by means of prolonged intermittent posio tive pressure ventilation (IPPV) through a trachece ostomy; details were given in a previous paperd (Ambiavagar et al., 1966). Each patient was nursed in a single room and hospital infection was minimised by standard techniques.

Bacterial monitoring consisted of daily cultures from wounds, the urine, tracheal aspirate, nose, $\mathscr{Q}$ throat, and blood and then identifying all the 
bacteria isolated. The results were then charted. Bacterial colonisation of the eyes, wounds or the respiratory tract was diagnosed when potential pathogens were cultured from these sites without evidence of inflammation or toxaemia. Infection was inferred when there were signs of inflammation or systemic signs of toxaemia or bacteraemia. Bacterial pneumonia (consolidation) following thoracic or other injuries is difficult to recognise radiologically. We have used the criteria previously determined in this unit (Gett et al., 1971). Consolidation is defined as 'opacities (homogeneous or irregular) in part or whole of a lung field with an air bronchogram'. Bacteraemic shock is a convenient label to describe a clinical syndrome which strongly suggests widespread organ damage due to bacterial toxins with or without bacteraemia (Levin, 1973). The clinical signs and abnormal test results are listed in Table 1.

Temperature was measured electrically with an electrode placed in the rectum and one strapped to the big toe. Haematological and biochemical measurements were made daily. Metabolic balance was maintained by the methods devised in this unit (Jones and Sechiari, 1963; Jones and Peaston, 1966). Acute renal failure was treated by means of frequent haemodialysis. Before July 1973 antibiotics were started only when there were signs of bacterial toxaemia and sometimes when the chest radiograph showed consolidation or collapse. After July 1973, a standard regimen of antibiotics was used according to the policy to be described. The concentration of gentamicin in the serum was measured by a plate diffusion technique, based on the method of Bennett et al. (1966).

\section{PATIENTS}

These were divided into two groups. The first group comprised all four patients with thoracic and other injuries admitted during a 10-month period (September 1972 to June 1973). All four had injuries requiring IPPV and all developed clinical features of bacterial toxaemia and died. Twenty patients were admitted over the next two years (July 1973 to September 1975) and 16 of these satisfied our criteria for treatment with antibiotics and formed the second group. Fourteen required IPPV and tracheostomy. The four patients who did not receive antibiotics all survived.

\section{Results}

\section{FIRST GROUP}

In each of the four patients, the respiratory tract was colonised by Gram-negative bacilli and, although repeated blood cultures were negative, features suggesting bacterial toxaemia appeared in all the patients. It was found that in each case a rapid rise in body temperature, white cell count or blood sugar preceded the clinical diagnosis of bacterial toxaemia by a period of at least 48 hours. The mean values for these parameters just before this rapid rise were-a rectal temperature of $38.5^{\circ} \mathrm{C}$, a white cell count of $11.0 \times 10^{\circ} / 1$, and a blood sugar of $11.2 \mathrm{mmol} / \mathrm{l}$. The number of observations were too few for statistical analysis, but it seemed possible that these values could be used to formulate an antibiotic policy for such patients.

\section{Antibiotic policy}

This was based partly on the signs described above and on additional criteria. They were: Gramnegative bacilli in stained films of the tracheal aspirate together with radiological evidence of consolidation or absorption collapse; laparotomy. The latter was included because of the high risk

Table 1 Clinical signs and abnormal test results associated with severe toxaemic infection

\begin{tabular}{|c|c|c|}
\hline System & Signs & Tests \\
\hline Cardiovascular & $\begin{array}{l}\text { Warm hypotension } \\
\text { Cold hypotension }\end{array}$ & $\begin{array}{l}\text { Increased cardiac output; reduced peripheral resistance; raised blood } \\
\text { lactate } \\
\text { Reduced cardiac output; increased peripheral resistance; raised blood } \\
\text { lactate }\end{array}$ \\
\hline Respiratory & $\begin{array}{l}\text { Respiratory distress syndrome of adults } \\
\text { Respiratory failure }\end{array}$ & $\begin{array}{l}\text { Hypoxaemia, hypocapnia, alkalosis; chest radiography normal or } \\
\text { shows pulmonary infiltrates } \\
\text { Hypoxaemia, hypercapnia, acidosis; apnoea; pulmonary oedema } \\
\text { on radiograph }\end{array}$ \\
\hline Blood & Bleeding & $\begin{array}{l}\text { Hypofibrinogenaemia; thrombocytopenia; increased } \\
\text { radiofibrinogen catabolism }\end{array}$ \\
\hline $\begin{array}{l}\text { Renal } \\
\text { Hepatic } \\
\text { Gastrointestinal }\end{array}$ & $\begin{array}{l}\text { Acute renal failure } \\
\text { Jaundice } \\
\text { Haemorrhage } \\
\text { Paralytic ileus }\end{array}$ & $\begin{array}{l}\text { Uraemia; increased plasma/urine osmolality } \\
\text { Hyperbilirubinaemia; raised SGOT and SGPT } \\
\text { Hypotension; tachycardia; low central venous pressure } \\
\text { High gastric aspirate; absent bowel sounds; dilated bowel and fluid } \\
\text { levels on abdominal radiograph }\end{array}$ \\
\hline Central nervous & Drowsiness, lethargy, confusion, and coma & \\
\hline
\end{tabular}


of bacteraemia (British Medical Journal, 1975) or increased absorption of bacterial toxin from the intestine (Caridis et al., 1972). The resulting list of indications was grouped under three headings as shown in Table 2; the policy was tested out on the second group of 16 patients.

Table 2 Indications for starting antibiotics

I Gram-negative bacilli in stained films of the tracheal
aspirate together with radiological evidence of
consolidation or absorption collapse
Two of the following:
a Rectal temperature of $38.5^{\circ} \mathrm{C}$ or more
b White blood cell count of $11 \cdot 0 \times 10^{\circ} / 1$ or above
c Blood glucose level of $11 \cdot 2 \mathrm{mmol} / 1(200 \mathrm{mg} / 100 \mathrm{ml})$
or above
or III Laparotomy

The antibiotics given were gentamicin and lincomycin (Table 3 ), each as bolus injections intravenously. They were chosen because in combination they have a wide range of activity against aerobic and anaerobic Gram-negative and Grampositive bacteria. To combat primary infection due to fungi, or indeed infection secondary to the antibiotics, nystatin was routinely administered into the trachea and the stomach. When previous bacterial monitoring suggested the presence of Ps. aeruginosa carbenicillin was added. The dose of gentamicin was adjusted to give peak and trough levels of $5-15 \mu \mathrm{g} / \mathrm{ml}$ and $5 \mu \mathrm{g} / \mathrm{ml} \mathrm{respec-}$ tively. The antibiotics were given for at least seven days and stopped according to one or more of the following criteria: weaning from the ventilator, return of the temperature and white cell count to normal, and a blood sugar in the range of 5.6$11.1 \mathrm{mmol} / 1$ without the need for insulin.

\section{SECOND GROUP}

Each of the 16 patients was colonised by one or more bacterial pathogens as shown in Table 4 , which also lists the indications for starting the antibiotic regimen. Organisms were not cultured from the blood in any of the 16 patients. Ten of the patients recovered and six died. Two deaths were caused by brain damage from head injury, one from biliary peritonitis, and one by progressive $\overrightarrow{\vec{\rho}}$ pulmonary oedema (post-traumatic pulmonary in sufficiency) due to fat embolism and saline excess흠 The remaining two deaths occurred in patients with clinical features of bacterial toxaemia $\stackrel{\varnothing}{\Omega}$ Patient 5 (Table 4) was given antibiotics after a laparotomy. Antibiotics were stopped on day $\mathcal{L}^{\circ}$ but on day 10 new indications appeared (I. IIa, $\mathrm{b}$ of Table 2). Antibiotics were restarted but clinica $\vec{\omega}$ signs of toxaemia appeared on day 15 and the? patient died the next day. The bacteria isolated. were sensitive to the antibiotics given. In patientw 8 , clinical signs of toxaemia appeared on the second day and preceded by one day the indicair tions (I, IIa of Table 2) selected for initiatingo antimicrobial therapy. Antibiotics were started ong the third day but the patient died the following day. In both groups of patients, this was the onlyo occasion on which the clinical features of toxaemia preceded those criteria chosen for start: ing antibiotic therapy.

\section{Discussion}

Our experience confirms the susceptibility of thes injured patient to colonisation by bacterial pathoo gens and the high mortality when clinical featureso and tests suggest the onset of bacterial toxaemia (Walter, 1971; Caridis et al., 1972). It is accepteb that the criteria used to diagnose bacteria $B$ toxaemia may also be seen in patients with acute? pancreatitis, severe ulcerative colitis or extensive burns, and that circulating endotoxins may or may not be the dominant causative factor. When a clinical diagnosis of bacterial toxaemia is madex and bacterial monitoring indicates a Gramnegative infection, then antibiotics are frequently. ineffective. In contrast, when infection is due to aO Gram-positive organism antibiotics are much more effective although these organisms can also cause? toxaemia (MacLean et al., 1967). The dilemmax which faces the clinician is when to start antibiotics in such patients. Although the antibiotic policy described has not been tested by a controlled trial, the results are very encouraging. The indicationso based on body temperature, white cell count, andw

Table 3 Antibiotic regimen used to treat the 16 patients in the second group

\begin{tabular}{|c|c|c|c|}
\hline \multirow[t]{2}{*}{ Antibiotic } & \multirow{2}{*}{ Dosage } & \multicolumn{2}{|c|}{ Administration } \\
\hline & & Frequency & Route \\
\hline $\begin{array}{l}\text { Carbenicillin } \\
\text { Lincomycin } \\
\text { Gentamicin } \\
\text { Nystatin suspension }\end{array}$ & $\begin{array}{l}5 \mathrm{~g} \\
600 \mathrm{mg} \\
80-240 \mathrm{mg} \\
100000 \text { units }\end{array}$ & $\begin{array}{l}\text { 6-hourly } \\
\text { 6-hourly } \\
\text { 8-hourly } \\
\text { 6-hourly }\end{array}$ & $\begin{array}{l}\text { Intravenous } \\
\text { Intravenous } \\
\text { Intravenous } \\
\text { Intragastric and intratracheal (nebulised by ventilator) }\end{array}$ \\
\hline
\end{tabular}


Table 4 Findings in the second group of patients

\begin{tabular}{|c|c|c|c|c|c|c|c|}
\hline Patient & Age & Injuries sustained & Treatment & $\begin{array}{l}\text { Eacterial } \\
\text { pathogen }\end{array}$ & Isolated from & Outcome & $\begin{array}{l}\text { Indications for } \\
\text { antibiotics }^{1}\end{array}$ \\
\hline 1 & 17 & Thoracic & IPPV & Staph. aureus & Tracheal aspirate & $\mathbf{S}$ & II $\mathbf{a}, \mathbf{b}, \mathbf{c}$ \\
\hline 2 & 20 & Thoracic & IPPV & Strep. faecalis & Tracheal aspirate & $\mathbf{S}$ & II $a, b, c$ \\
\hline 3 & 35 & $\begin{array}{l}\text { Thoracic, limb, and pelvic } \\
\text { fractures; fat embolism }\end{array}$ & $\begin{array}{l}\text { IPP breathing; } \\
\text { heparin }\end{array}$ & Klebsiella spp & Sputum & $\mathbf{S}$ & II $\mathbf{a}, \mathbf{b}$ \\
\hline 4 & 20 & $\begin{array}{l}\text { Torn liver and hepatic duct; } \\
\text { limb fractures }\end{array}$ & $\begin{array}{l}\text { IPPV; } \\
\text { haemodialysis; } \\
\text { laparotomy }\end{array}$ & $\begin{array}{l}\text { Proteus spp, } \\
\text { Candida } \\
\text { albicans }\end{array}$ & Trachael aspirate & $\begin{array}{l}\text { D, biliary } \\
\text { peritonitis }\end{array}$ & II a, b \\
\hline 5 & 70 & $\begin{array}{l}\text { Thoracic; perforated } \\
\text { duodenum }\end{array}$ & $\begin{array}{l}\text { IPPV; } \\
\text { closure of } \\
\text { perforation }\end{array}$ & Klebsiella spp & Tracheal aspirate & $\begin{array}{l}\text { D, bacterial } \\
\text { toxaemia }\end{array}$ & $\begin{array}{l}\text { III day } 2 \\
\text { I, II a, b day } 10\end{array}$ \\
\hline 6 & 38 & Thoracic; torn liver & $\begin{array}{l}\text { IPPV; partial } \\
\text { hepatectomy }\end{array}$ & Staph. aureus & Throat & $\mathbf{S}$ & III, II c \\
\hline 7 & 17 & $\begin{array}{l}30 \% \text { burns, soft tissue damage, } \\
\text { limb fractures }\end{array}$ & $\begin{array}{l}\text { IPPV; } \\
\text { amputation of } \\
\text { limb }\end{array}$ & Ps. aeruginosa & $\begin{array}{l}\text { Tracheal aspirate, } \\
\text { burns }\end{array}$ & $\mathbf{S}$ & I, II a \\
\hline 8 & 34 & $\begin{array}{l}\text { Head, thoracic, limb, and } \\
\text { pelvic fractures }\end{array}$ & IPPV & Ps. aeruginosa & Tracheal aspirate & $\begin{array}{l}\text { D, bacterial } \\
\text { toxaemia }\end{array}$ & I, II a \\
\hline 9 & 23 & $\begin{array}{l}\text { Head; inhalation of vomit; } \\
\text { limb fractures }\end{array}$ & IPPV & Esch. coli & Tracheal aspirate & $\mathbf{s}$ & I, II a \\
\hline 10 & 44 & $\begin{array}{l}\text { Head; inhalation of vomit; } \\
\text { traumatic pancreatitis }\end{array}$ & $\begin{array}{l}\text { IPPV; } \\
\text { haemodialysis; } \\
\text { laparotomy; } \\
\text { aprotinin; } \\
\text { glucagon }\end{array}$ & Klebsiella spp & Tracheal aspirate & $\begin{array}{l}\text { D, brain } \\
\text { damage }\end{array}$ & I, II a \\
\hline 11 & 21 & Thoracic; torn spleen & $\begin{array}{l}\text { IPPV; } \\
\text { haemodialysis; } \\
\text { splenectomy }\end{array}$ & $\begin{array}{l}\text { Klebsiella spp, } \\
\text { Ps. aeruginosa }\end{array}$ & Throat & $\begin{array}{l}\text { D, post } \\
\text { traumatic } \\
\text { pulmonary } \\
\text { insufficiency }\end{array}$ & III \\
\hline 12 & 22 & $\begin{array}{l}\text { Head, thoracic, and pelvic } \\
\text { fractures }\end{array}$ & $\begin{array}{l}\text { IPPV; } \\
\text { peritoneal } \\
\text { dialysis }\end{array}$ & Ps. aeruginosa & Tracheal aspirate & $\begin{array}{l}\text { D, brain } \\
\text { damage }\end{array}$ & II a, b, c \\
\hline 13 & 57 & Thoracic & IPPV & $\begin{array}{l}\text { Esch. coli, } \\
\text { Proteus spp }\end{array}$ & Tracheal aspirate & $\mathbf{S}$ & I, II c \\
\hline 14 & 10 & $\begin{array}{l}\text { Head, thoracic, and limb } \\
\text { fractures }\end{array}$ & IPPV & Ps. aeruginosa & Tracheal aspirate & $\mathbf{S}$ & II $\mathbf{a}, \mathbf{b}$ \\
\hline 15 & 34 & $\begin{array}{l}\text { Soft tissue damage; pelvic } \\
\text { crush injury }\end{array}$ & $\begin{array}{l}\text { Haemodialysis; } \\
\text { excision of } \\
\text { necrotic tissue }\end{array}$ & $\begin{array}{l}\text { Cl. welchi, } \\
\text { Bacteroides spp, } \\
\text { Esch. coli, } \\
\text { Candida } \\
\text { albicans }\end{array}$ & $\begin{array}{l}\text { Wound } \\
\text { Urine }\end{array}$ & $\mathbf{S}$ & III, II a \\
\hline 16 & 61 & Thoracic; torn liver and spleen & $\begin{array}{l}\text { IPPV; } \\
\text { splenectomy; } \\
\text { partial } \\
\text { hepatectomy }\end{array}$ & Ps. aeruginosa & Tracheal aspirate & $\mathbf{S}$ & III \\
\hline
\end{tabular}

See Table 2.

$\mathbf{S}=$ survived; $\mathbf{D}=$ died.

glucose intolerance are, of course, not specific to bacterial infection or toxaemia and can be due to either inflammation or the metabolic response to injury (Taylor, 1965; Walker and Johnston, 1971; Sevitt, 1974).

It would greatly help the clinician to have a laboratory test which would show when colonising bacteria become invasive. Two such tests have been studied, the nitrobluetetrazolium test (Freeman et al., 1973) and the limulus lysate assay for endotoxin (Caridis et al., 1972; Stumacher et al., 1973; Wardle, 1975). Unfortunately, neither test has proved satisfactory in detecting infection in clinical practice (Levin, 1973; Ward, 1974; Elin et al., 1975). We believe that the high death rate from bacterial toxaemia will be reduced only by adopting measures which are designed to prevent bacteria from colonising and subsequently infecting the patient. In the future it may be possible to maintain the immunity of the injured patient or to neutralise circulating endotoxin (Cuevas et al., 1974; Wardle, 1975).

An alternative policy would be to give antibiotics routinely to all patients with severe injuries. Experience has shown that such prophylactic usage leads to harmful infection by resistant bacteria (Price and Sleigh, 1970). It is highly probable that the indiscriminate use of gentamicin or tobramycin would result in the emergence of resistant strains and reduce the available therapy for treating resulting infections. We believe that the most effective policy is to use antibiotics according to readily available criteria such as those described. 
We are indebted to Dr. Alan Percival for advice on the treatment of the patients. The studies were made possible by a grant from the Research Committee of the Regional Health Authority (Teaching).

\section{References}

Ambiavagar, M., Robinson, J. S., Morrison, I. M., and Jones, E. S. (1966). Intermittent positive pressure ventilation in the treatment of severe crushing injuries of the chest. Thorax, 21, 359-366.

Bennett, J. V., Brodie, J. L., Benner, E. J., and Kirkby, W. M. M. (1966). Simplified accurate method for antibiotic assay of clinical specimens. Applied Microbiology, 14, 170-177.

British Medical Journal (1975). Bacteraemia from the bowel (Leading article). British Medical Journal, 3, 396-397.

Caridis, D. T., Reinhold, R. B., Woodruff, P. W. H., and Fine, J. (1972). Endotoxaemia in man. Lancet, 1, 1381-1386.

Cuevas, P., Fine, J., and Monaco, A. P. (1974). Successful induction of increased resistance to gramnegative bacteria and to endotoxin in immunosuppressed mice. American Journal of Surgery, 127, $460-464$.

Elin, R. J., Robinson, R. A., Levine, A. S., and Wolffe, S. M. (1975). Lack of clinical usefulness of the limulus test in the diagnosis of endotoxaemia. New England Journal of Medicine, 293, 521-524.

Freeman, R., King, B., and Hambling, M. H. (1973). Infective complications of open-heart surgery and the monitoring of infections by the NBT test. Thorax, 28, 617-621.

Gett, P. M., Jones, E. S., and Shepherd, G. F. (1971). Pulmonary oedema associated with sodium retention during ventilator treatment. British Journal of Anaesthesia, 43, 460-470.

Jones, E. S., and Peaston, M. J. T. (1966). Metabolic care during acute illnesses. Practitioner, 195, 271275.
Jones, E. S., and Sechiari, G. (1963). Method fot? providing metabolic balance during intensive patient care. Lancet, 2, 19-20.

Lancet (1964). A unit for intensive care. Lancet, $1 \frac{\overline{\bar{p}}}{\bar{p}}$ $657-658$.

Levin, J. (1973). Endotoxin and endotoxemia. Nen England Journal of Medicine, 288, 1297-1298.

MacLean, L. D., Mulligan, W. G., McLean, A. P. H. $\overrightarrow{0}$ and Duff, J. H. (1967). Patterns of septic shock inman: a detailed study of 56 patients. Annals ot Surgery, 166, 543-562.

Price, D. J. E., and Sleigh, J. D. (1970). Control of infection due to klebsiella aerogenes in a neurow surgical unit by withdrawal of all antibiotics? Lancet, 2, 1213-1215.

Sevitt, S. (1974). Reactions to Injury and Burns, ando their clinical importance, p. 128. Heinemann London.

Stumacher, R. J., Kovnat, M. J., and McCabe, W. R(1973). Limitations of the usefulness of the limulus assay for endotoxin. New England Journal of Medio cine, 288, 1261-1264.

Taylor, W. H. (1965). Fluid Therapy and Disorders of Electrolyte Balance, p. 31. Blackwell Scientific Pubs lications, Oxford.

Walker, W. F., and Johnston, I. D. A. (1971). Meta bolic Basis of Surgical Care, p. 69. Heinemanno London.

Walter, C. W. (1971). The bacterial element in septic shock. In Septic Shock in Man, edited by S. G? Hershey, L. R. M. Del Guercio, and R. McConn, pp. 27-33. Little Brown, Philadelphia.

Ward, M. (1974). The nitroblue tetrazolium test $\frac{\text { 의 }}{3}$ British Journal of Hospital Medicine, 12, 351-358.

Wardle, E. N. (1975). Endotoxinaemia and the pathoo genesis of acute renal failure. Quarterly Journal of Medicine, 44, 389-398.

Requests for reprints to: Dr. E. Sherwood Jones, Intensive Care Unit, Whiston Hospital, Prescot? Merseyside, UK. 